\title{
PRACTICE-ORIENTED APPROACH IN THE SYSTEM OF PROFESSIONAL TRAINING OF FUTURE TEACHERS TO SOCIAL- PEDAGOGICAL ACTIVITY
}

\author{
OLENA BUDNYK
}

\begin{abstract}
The article highlights theoretical aspects of the socio-pedagogical direction of pedagogical practice of future primary school teachers. The tasks of pedagogical practice as a mandatory component of professional training of future specialists are outlined. The necessity of involvement employers in cooperation with higher education institutions to ensure a high level of continuous practical training, creating conditions for professional development and self-realization of future teachers are substantiated. Great emphasis is placed on the need for creative use of theoretical knowledge and practical skills working with students, modern teaching technologies, students' educational and social development, as well as systematic professional self-improvement and self-development. It was proved that in the process of teacher training system pedagogical practice performs a number of important functions: educational, developmental, diagnostic and corrective, communicative, organizational (management), prognostic, preventive, etc. The approximate content of this student practice in general educational institutions is given taking into account such directions, as: work with deviant and gifted pupils, inclusive education, sociocultural animation, etc. The results of an empirical study on the readiness of graduates of pedagogical specialties for the practical use of social and educational technologies in school are presented. The difficulties most often faced by respondents in working with students were identified, including: work with different categories of parents, individual counseling of students, resolution of pedagogical conflicts, implementation of diagnostic activities and socio-pedagogical communication, etc. The author proved that combination of theoretical and practical teacher training, integration of teaching with research and experimental work would contribute to the practical orientation of the educational process at the university, active search and implementation of non-traditional forms and methods of teaching, in particular in socio-pedagogical aspects.

The article partially uses the materials of the author's dissertation "Theoretical and methodological principles of professional training of future primary school teachers for socio-pedagogical activities" (2015) for the degree of Doctor of Pedagogical Sciences.
\end{abstract}

Keywords: teacher training, primary school, pedagogical practice in school, practice-oriented approach, pedagogical university, socio-pedagogical activity.

\section{INTRODUCTION}

Integration into the world educational space, academic mobility, globalization determine the problem of training a competitive in the labor market graduate of a higher education institution who is able to use the acquired competencies in practice professionally. This is especially related to the modern teacher, as requirements for his/her innovative readiness and ability to use theoretical knowledge in 
non-standard situations are growing. "Education for professional or occupational practice extends beyond the time, place and intention of university curricula and includes initial preparation for the occupation and ongoing development across the working life" [5, p. 72]. Training of qualified specialists should be carried out with constant consideration of social challenges, development of science and technology, and should be connected with the realities of practice. First, it concerns the training of a modern teacher, who must be creative, have digital and social skills [3].

In modern conditions, professional functions of a teacher as a subject of socio-pedagogical activities, the subject of which is the socio-cultural education of students on the basis of innovative renewal and humanistic paradigm; creating conditions for their effective adaptation to the educational process; development of personally significant values for successful socialization in school; prevention of antisocial phenomena and actions, timely overcoming of pupils' crisis situations; creating appropriate conditions for the formation of a socially active personality by activating pedagogical potential of society. These and other problems must be solved in school practice. At the same time, in the context of the economic and political crisis, the number of disadvantaged families in society is growing, which is a prerequisite for the trend of increasing deviations among juvenile in the modern educational environment. In addition, the coronavirus pandemic has increased psychological anxiety among participants of the educational process who need appropriate pedagogical support. The emphasis of the student's social education is automatically shifted to the professional activities of schools and community. Therefore, in the process of future teachers training, we consider the use of social and educational technologies in professional practice to be relevant.

The purpose of this article is to highlight the features of the organization of pedagogical practice of future primary school teachers in Ukrainian higher education institutions and to present the results of monitoring the professional readiness of graduates to implement socio-pedagogical functions in primary school practice.

\section{RESUlTS AND DISCUSSION}

\section{1. Features of the Organization of Students' Pedagogical Practice in School (SPECIALITY “PRIMARY EDUCATION")}

The educational policy of a number of countries (for example, Ukraine) is aimed at obliging educational institutions to provide quality educational services at a level determined jointly with the employer; to provide a high level of continuous practical training, to create conditions for professional development and professional self-realization of students and graduates, etc. [7]. It is about attracting employers to cooperate with universities not only as a teaching practice base, but also as possible solution for providing graduates with first jobs.

In addition, this is not accidental, because the problem of employment of future specialists in Ukraine, as in other countries, is particularly significant. There is growing competition in the labor market for creative teachers who are able to provide quality educational services for children. It is during the period of various types of practice in primary school when appropriate conditions are created to identify their abilities for socio-pedagogical activities, communication with teachers and school administration, which is an effective means of possible employment in the same institution after graduating from pedagogical institute.

The task of pedagogical practice as a mandatory component of professional training of future teachers is to teach students creatively use theoretical knowledge and practical skills in teaching, to promote modern technologies of teaching, education and social development of students, to form the need for systematic professional self-improvement and self-development. "The student's activity in the period of pedagogical practice is analogous to the professional activity of a teacher; it is organized in the real conditions of the educational institution" [10, p. 647]. Accordingly, a future specialist has the opportunity to comprehend and analyze socio-pedagogical phenomena, situations, patterns and principles of the educational process in order to master properly the experience of the chosen profession. 
Approximate content of pedagogical practice of future primary school teachers:

1) preparatory practice: participation in the guidance meeting on the organization of pedagogical practice, acquaintance with methodological recommendations and requirements for teaching, educational and research work of socio-pedagogical direction;

2) acquaintance with the school administration and teaching staff; inspection of offices, their equipment and design; study of thematic and lesson plans of primary school teachers; analysis of curricula and textbooks on professional methods of primary school; planning own educational and methodical work for the period of practice;

3) psychological and pedagogical study of primary school class using experimental techniques: the method of rating, ranking, pedagogical experiment, sociometry, training and others, making psychological and pedagogical characteristics of the student group;

4) preparation for lessons in primary school, their discussion (according to the calendar plan); observation of lessons and educational activities of class teachers, students-interns, participation in their discussion; selection and preparation of didactic materials and multimedia presentations for classes; ensuring the educational nature of education; development of cognitive activity and creative talent of students; individual educational work with children of primary school age.

5) performing a class teacher's functions; socio-pedagogical activities on propaedeutics and correction of pedagogical neglect, delinquency and juvenile delinquency; participation in parent meetings, lectures, visiting students at home, consultations for parents invited to school;

6) methodical and research activities: systematic maintenance of practice diary and other documentation; study of the best school teachers' experience; participation in school council meetings, methodical meetings of class teachers and subject commissions; preparation of photo materials for the exhibition and participation in the final reporting conference on the results of practice in primary school; work on the diploma (master's) work on the chosen topic.

In the context of involving students in socio-pedagogical activities, we rely on a practice-oriented approach in the process of training of future primary school teachers. After all, "pedagogical practice an orderly set of real actions, knowledge, skills and abilities of teachers, concentrated in certain points of social space within the specific social roles", because mastering specific practical actions presented in pedagogical culture, including folk, a person acquires his/her social certainty, a certain status in society [8].

In the system of professional training of teachers, pedagogical practice performs a number of important functions: educational, developmental, educative, diagnostic-corrective, communicative, organizational (managerial), prognostic, preventive and others. [1].

The educational function involves actualization, deepening and application of theoretical knowledge, formation of various pedagogical skills and abilities. The prerogative of the developmental function is development of future teachers' cognitive and creative activity, their pedagogical thinking. In the course of the educational function, students' worldview culture, their social activity, professionally significant and professionally important qualities of a teacher are formed. The content of the diagnostic function is to check the level of future teachers' professional orientation, the degree of their professional training and suitability for pedagogical activities. The communicative function is to establish social interaction of the teacher's personality with all participants of the educational process in the micro-society; organizational (managerial) - characterizes pedagogical activities in terms of social management, which means structuring, planning, distribution of various activities, coordination of work with various social institutions; management of students' socio-cultural education in the conditions of open social and pedagogical system, and also students' ability to organize children's group; prognostic - means predicting results of activities; diagnostic and corrective - is the timely detection of social anomalies in a particular micro-society, formation and improvement of socially significant personality traits, creating conditions for participation in society; preventive - aims to prevent antisocial phenomena and actions, to create appropriate conditions for the formation of a socially active personality. 
Based on the functions of socio-pedagogical activities, we determine its content, and we consider the methodological training of the graduate to be mastering the relevant technologies. The technological approach in education involves modeling, so the model is considered any pedagogical technology, but not every model can be a technology, but only one with specific features: conception, controllability, optimality, etc. Therefore, the difference between technology and the model of teaching (education) is that the model is a general scheme of functioning of the main components of the socioeducational process, and technology is built on a diagnostic basis, clearly controlled and adjusted model designed to achieve a guaranteed result. [6, p. 170-177].

The essence of socio-pedagogical technology is in the operationalization of the educational process, the creation of an algorithm of subject-subject interaction of the teacher with students and their parents. Socio-pedagogical technology (according to $\mathrm{N}$. Zaveryko) is characterized by universality of application, constructiveness, efficiency, efficiency in its temporal implementation, relative ease of use, reliability, flexibility [12, p. 513-514].

Familiarization of future primary school teachers with socio-pedagogical technologies is quite fully carried out in lectures and practical classes in pedagogical disciplines using business and role-playing games, discussions, creative tasks, microteaching, case studies, modeling, mini-research, etc. [2].

From the technologies described in the modern scientific and pedagogical literature, it is necessary to single out those that most correspond to the outlined areas of professional activity of primary school teachers and are aimed at ensuring its effectiveness. These are technologies for the development of the student's creative personality, interactive, project, information and communication, health care, etc. Some of them should be implemented by involving students in practical development of the mechanism of their use, fulfillment of appropriate social roles (teacher, student, father, and school staff) and testing in the process of pedagogical practice at school.

\subsection{Monitoring of Graduates' Professional ReAdiness for the Performing of SOCIAL AND EdUCATIONAL FUnCTIONS IN PRIMARY SCHOOL PRACTICE}

In the context of students' training for socio-pedagogical activities in primary school, we consider it appropriate in the process of teaching of pedagogical disciplines to emphasize the content, areas and functions of relevant activities.

Thus, an important area of pedagogical practice is working with pupils' deviant behavior. To find out whether students are familiar with the content and methodology of this kind of work before pedagogical practice, a survey was conducted. To the question: "What is deviant behavior?" the following answers were received: deviant behavior is "behavior that does not meet the norms of society" (58.8\%), "inappropriate behavior" (12.4\%), "behavior of children with mental disorders" (9.3\%); "negative behavior" (3.1\%). Accordingly, socially vulnerable children, according to graduate students, are "students who are not adapted to life in the environment" (5.2\%), "students who lack social protection" (33\%), "students from disadvantaged families" (55.7\%), "students affected by the natural disaster" $(1.03 \%)$; and pedagogically neglected children are "children who were not given proper attention" (20.6\%), "students who lack the attention of the teacher" (33\%), "students who lag behind in learning" (30.9\%), "difficult-to-raise children" (12.4\%), "children to whom appropriate methods of upbringing have not been applied" (5.2\%). We consider such students' readiness to solve the outlined task in school practice to be insufficient.

Socio-pedagogical activity also involves teachers' systematic reflective activity, i.e. the ability to evaluate results, to correlate their own motives and actions with socio-cultural values, knowledge and beliefs of other participants of the educational process (students, parents, educators, psychologist, social educators, etc.), the desire for self-improvement, self-development and self-esteem. According to the survey results, students gave the following explanations of the concept "reflection": "ability to feel, reproduce acquired knowledge" (13.4\%), "ability to act in certain situations" (10.3\%), "method of selfknowledge", "process of fixing one's own development "(18.6\%), "self-awareness as a teacher " $(6.2 \%)$, "ability to work in educational institutions" (3.1\%). Thus, a small number of future teachers 
identify reflection with the body's automatic stereotypical reaction to environmental stimuli: "the ability to respond to certain factors" (8.2\%), "the ability of individuals to express their reflexes automatically" $(3.1 \%)$, or even confuse with the term "relaxation" $(2.1 \%$ of respondents indicated that reflection is a "state of relieving fatigue, tension in the pedagogical process"), which is evidence of their complete misunderstanding of the essence of the outlined concept.

In the modern world there is an increase in number of children with mental and physical disabilities, so together with the humanization of education in many countries around the world one of the forms of education of children with special educational needs is recognized as an inclusive form [11]. The main emphasis is shifted to ensuring equal access to quality education for children with disabilities by organizing their education in secondary schools based on the use of personality-oriented teaching methods, taking into account individual characteristics of training and professional psychological and pedagogical support. Therefore, one of socio-pedagogical activities of primary school teachers is work in conditions of inclusive education. However, students, as our observations show, still have difficulty teaching an inclusive class. It is sometimes difficult for them to adapt the content of education, forms and methods of working with children with special educational needs, to determine the specifics of assessing learning outcomes, as well as to establish cooperation with parents or other specialists in psychological and pedagogical support. Most Ukrainian universities pay considerable attention to the study of the basics of inclusive education, but graduates often lack practical skills of applying certain methods of working with children of a certain nosology. At the same time, not all students get pedagogical practice in a class with inclusive education. Accordingly, it is difficult for them to model the relevant lessons according to the methods of working with children with special needs.

In the context of adaptation of Polish higher education to the requirements of the Bologna process, the country has intensified professional training for work in the socio-pedagogical sphere. Thus, in universities the main task of professional education of teachers is their mastery of general competencies based on the acquisition of knowledge in the humanities, social and medical sciences in order to understand the socio-cultural context of educational reality. Regardless of the chosen specialty, future teachers master theoretical knowledge with anthropological practice as a basis for developing skills and abilities to diagnose and work with children with special needs in school, professional or local environment within their "social competencies". For example, at the specialties "Pedagogy of Guardianship and Therapy", "Psychological and Pedagogical Counseling and Assistance", "Resocialization", "Education and rehabilitation of people with special needs", future professionals receive professional competencies that give them the right to work not only in social services for children and youth, social prevention centers, guardianship centers, rehabilitation institutions and others, but especially to work at school with different categories of children and their parents [2].

Another important aspect of the socio-pedagogical activity of primary school teachers is sociocultural animation, the content of which most graduates of pedagogical educational institutions (72.2\%) could not explain; only about a third of them (27.8\%) gave not quite correct answers: "when a teacher uses various innovative technologies", "a certain status, ideal of behavior that requires appropriate behavior of the individual in relation to the group", "activities related to society and creativity", "field of pedagogy, which aims at forming general human culture", "ability to reproduce certain sociocultural norms" and so on. We considered these data in the process of developing methodological support for pedagogical practice at school.

To identify the readiness of future teachers to solve certain professional tasks, we found that almost half of respondents (48.4\%) indicated students' socialization and development among priorities of primary education. This fact proves that modern students are aware of the urgency of the problems of a child's social upbringing, which is primarily due to his/her entry into the school socio-cultural environment. Thus, $36 \%$ of respondents ranked students' mastery of the system of scientific knowledge as the most important, i.e. the didactic function of the pedagogical process and $18.6 \%$ pointed to the primary need for educational influence on the individual. 
Answering the question "Which functions of a primary school teacher are you most prepared for?" graduates indicated educational (76.3\%), developmental (60.8\%), organizational (managerial) (59.8\%), didactic (42.3\%), educational and methodological (35.1\%), research creative (33\%). However, according to the survey, only a small number of students admitted their readiness for the prognostic function of professional activity $(4.1 \%)$, diagnostic and corrective $(3.1 \%)$, preventive $(5.2 \%)$, etc., i.e. those that involve social and educational interaction with primary school students and their parents.

In the process of professional training of future teachers for socio-pedagogical activities, it is important to emphasize the features of the implementation of certain functions in school as an open socio-pedagogical system. After all, the socialization of primary school students is characterized by specific phenomena, in particular, students' desire to really participate in public life, to join children subculture, to master certain social roles, and so on. The peculiarity of their mastery of socio-cultural experience is too emotional, so these issues are especially important at primary school age. Thus, pedagogical neglect of primary school students' socio-cultural needs, their life experience often leads to deformations of personal development, which occurs latently, and therefore is often not observed by teachers and parents. Thus, according to our observations, most deviations in adolescent behavior originate from primary school and arise based on their external well-being. Similarly, we can argue about the talent or leadership that often is unnoticed in elementary school. Such typical situations significantly affect the content and nature of teachers' socio-pedagogical activities, as well as the system of his/her professional training.

Taking into account the above data, we got logical and natural response to the question "What aspects of professional training, in your opinion, are not carried out enough at the pedagogical faculty?" (Table 1).

According to the results in Table. 1, graduates of pedagogical universities admitted that they mostly have theoretical knowledge in pedagogical disciplines $(94.8 \%)$, but consider themselves insufficiently ready to work with different categories of parents (47.4\% of respondents), individual work with children (37.1\%), resolution of pedagogical conflicts (36.1\%), experience gaps in the implementation of diagnostic activities (17.5\%), socio-pedagogical communication (15.5\%). Only a small part of the respondents indicated such important qualities of a teacher as his/her moral and aesthetic culture $(4.1 \%)$ and worldview, civic position (3.1\%). Therefore, we consider it appropriate to focus on these aspects of youth training. After all, according to the study, $52.6 \%$ of respondents consider communicative qualities to be among the most important qualities of a teacher in establishing subjectsubject relationships; $32 \%$ - moral and aesthetic, $27.8 \%$ - motivational activity and personality orientation and only $6.2 \%$ of future professionals named worldview qualities that should be taken into account in the process of preparing students for pedagogical practice in primary school.

\begin{tabular}{|l|c|}
\hline \multicolumn{1}{|c|}{ Aspects of professional training } & $\begin{array}{c}\text { Amount of } \\
\text { students, } \%\end{array}$ \\
\hline Training for work with different categories of students' parents & 47,4 \\
\hline Development of skills of individual work with children & 37,1 \\
\hline Formation of skills for resolving pedagogical conflicts & 36,1 \\
\hline Subject-methodical training & 27,8 \\
\hline Development of organizational skills (educational upbringing) & $18,6 \%$ \\
\hline Formation of diagnostic skills & 17,5 \\
\hline Formation of communication skills & 15,5 \\
\hline Formation of the teacher's moral and aesthetic culture & 4,1 \\
\hline Formation of students' worldview, civic position & 3,1 \\
\hline Preparation for pedagogical creativity, scientific work & 3,1 \\
\hline
\end{tabular}

Tab. 1. The results of the study of gaps in the future teachers' practical training.

Suggesting respondents to rank these aspects as for significance, we obtained the following results (Table. 2). As you can see from the table, the first place in the hierarchy of professional qualities of 
future primary school teachers is given to love for children; the second - professional competence and the third rank - high moral virtues. It is encouraging that the fourth and fifth positions respectively are given to suitability for teaching activities and high intellectual development of the teacher's personality. A little bit surprised that such individual qualities as physical and mental health, without which any activity is inconceivable, as well as ability to work, temperament, motives, ranked seventh; communicative (interactive) qualities - eighth; aesthetic - ninth; organizational skills - tenth. Namely, these characteristics are the basis for the effective implementation of socio-pedagogical activities. High level of empathy, professional reflection and status-positional qualities also did not take their rightful place in the ranking table, which is evidence of insufficient understanding of their importance in establishing socio-pedagogical interaction with primary school students and their parents, correcting the negative impact of social and environmental factors.

\begin{tabular}{|c|l|c|}
\hline № & \multicolumn{1}{|c|}{ Professional qualities of a teacher } & Rank \\
\hline 1. & $\begin{array}{l}\text { Individual qualities (physical and mental health, ability to work, temperament, } \\
\text { motives) }\end{array}$ & 7 \\
\hline 2. & Status-positional (features of a person's social status, relations in a team) & 13 \\
\hline 3. & Communicative (interactive) qualities & 8 \\
\hline 4. & Suitability for teaching & 4 \\
\hline 5. & Activities & 14 \\
\hline 6. & Worldview-ideological (ideological-political beliefs, social activity) & 5 \\
\hline 7. & High intellectual development & 9 \\
\hline 8. & $\begin{array}{l}\text { Aesthetic qualities (the ability to perceive the world according to the laws of } \\
\text { beauty, the ability to see and understand the beautiful in human relationships) }\end{array}$ & 10 \\
\hline 9. & Organizational culture & 12 \\
\hline 10. & High level of empathy & 6 \\
\hline 11. & Readiness for pedagogical creativity and self-education & 3 \\
\hline 12. & Professional reflection & \begin{tabular}{l}
$|c|$ \\
\hline 13.
\end{tabular} \\
\hline 14. & Moral qualities (personal responsibility, purposefulness, honesty, humanity, \\
\hline 15. & Pove for children & 2 \\
\hline
\end{tabular}

Tab. 2. Graduates' of pedagogical universities of Ukraine ranking of primary school teacher's professional qualities by importance.

Alarming is the fact that the ideological and worldview qualities ranked the last place. This is explained, first, by a lack of awareness of the essence of social activity of the teacher, the importance of his/her ideological beliefs, worldview culture in professional activities; secondly, indifference to sociopolitical events in the country, lack of motivation to participate in public work, philanthropy, etc.

The study of foreign training shows that considerable attention is paid to the organization of student practice. For example, we are impressed that at the University of Cyprus an important aspect of practice is the creation of video clubs for future teachers [4]. Here they have the opportunity to demonstrate fragments of their lessons, talk about their successes and failures, and take into account their colleagues' views on working with students. Video Clubs into teacher education programs identify significant components for teaching and learning interpret components based on teacher professional knowledge. Teachers were documented shifting from simply noticing pupils' ideas and actions to more thoroughly analyzing pupils' thinking from offering alternative strategies to those viewed to gradually understanding the teaching strategies used [9]. This is quite an interesting experience that is worth implementing in other pedagogical universities. Thus, for three years of training, future teachers in Cyprus are engaged in Field Placement. During the first year, they teach lessons but do not practice video. The second year - Field Placement, Videos, and Video Clubs. This 
experience is extended to the third year of practice, when they create videos of their lessons and participate in Video clubs for 10 weeks. It also develops their communication skills, self-confidence and public speaking skills.

A good tradition in Ukrainian pedagogical educational institutions, such as Vasyl Stefanyk Precarpathian National University, is to hold graduates' reporting scientific and practical conferences of the specialty "Primary Education" based on the results of pedagogical practice at school. Teachersmethodologists of professional disciplines of primary education attend such events, schoolteachers are invited, and student interns have the opportunity to share their impressions of independent pedagogical steps in school practice, the difficulties encountered in preparing for lessons and educational activities, to express wishes for preparation to pedagogical practice for 4th year students. Such public reports, student reports, accompanied by multimedia presentations, videos from school practice, photo exhibitions, are valuable for teachers-methodologists to improve the process of preparation for pedagogical practice in the future. Based on the results of the reports the best pedagogical portfolio collected during practice in primary school, or a video with schoolchildren participation is considered the winner.

\subsection{InVolvement of Future Primary School Teachers in Socio-Pedagogical Activities in the Process of Pedagogical Practice}

In the process of studying at the Pedagogical University, future primary school teachers are involved in various types of practice, which we see inexhaustible opportunities for their participation in various areas of socio-pedagogical activities (professional prevention, work with gifted and deviant students, cooperation with parents, socio-cultural animation, activities in the context of inclusive education, etc.). In this context, it is important to emphasize that the nature of the child's perception of educational influences largely depends on his/her perception of the teacher's personality. Therefore, in social and communicative activities, the teacher directs himself/herself to professional reflection, clearly answering some questions, including: How do my students perceive me? Do they consider me a humane and fair person? Do they like the style of my communication? Do I know their experiences, intentions, cognitive needs? What are the possible difficulties in the process of implementing their selfeducation program? Etc.

In the process of pedagogical practice, students have the opportunity to systematically contact with students and their parents, as they fully perform the functions of primary school teachers, participate in methodological meetings, parent meetings, have the opportunity to use social and educational technologies to work with primary school children and their parents.

Future specialists are given the task of studying the peculiarities of socialization of primary school students in secondary school, identifying gifted students, creating for them a program to develop their creative, intellectual or physical abilities, as well as socially and pedagogically neglected children and developing individual programs to work with them and their parents.

The results of diagnostics, which are carried out with the help of methods of observation, telephone survey, questionnaire (interview), individual group interviews, we use in the preparation of student research papers.

An effective means of socio-pedagogical activities during pedagogical practice is educational work aimed at socio-cultural development of children. For example, in Ivano-Frankivsk specialized school of I-III levels \# 5 with intensive study of German, which is the basis of practical training for Vasyl Stefanyk Precarpathian National University graduates, systematic educational activities such as: "My mother tongue", "My family", "I am a schoolchild", "We are your children, Ukraine", "Let's be healthy", "In the world of good", etc. are held, reflecting the social aspect of pedagogical interaction. Therefore, methodologists emphasized the necessity for individual social influence, in particular, the social and communicative function of the teacher in educational communication with students for pedagogical adjustment of socio-cultural development. This reveals the constructive-projective, correctionaldevelopmental and organizational skills of students. 
In the reporting documentation, based on the results of pedagogical practice, graduates provide a description of the class and psychological and pedagogical characteristics of an individual pupil based on collected factual materials that reflect the diagnostic and analytical skills of the future specialist. According to individual - group conversations with students, they experienced the greatest difficulties while communicating with students' parents, as well as because of uncertainty and fear of speaking before the audience, lack of communication skills, and social rejection by students from low-income families, excessive aggression of individual children, etc. Another reason causing difficulties in working with students - no experience in "keeping discipline in class", inability to implement organizational impact on the group due to some hyperactive children. Therefore, a small number of future teachers noticed the complexity of modern programs and textbooks for primary school and their inconsistency with the age characteristics of students, their educational overload, exceeding the norms of planned occupancy.

Here are excerpts from students' reflections after pedagogical practice in primary school.

Iryna Sh.: "Modern students, as I noticed at school, respect mostly the strong, the rich... I think that a teacher should instill in students love and respect for people, regardless of their financial situation. As they say, rich materially, but poor mentally. In their careers, parents forget about their children, they lack care and affection, so their love is compensated by material values... and sometimes it is more important for a student to hear kind words than to get an expensive smartphone...".

Vira A.: "Lack of spirituality prevails among parents and students in a modern school, power and material things dominate. Is this correct? After all, in our time it was all different, although it was not so long ago. We played simple games and enjoyed life... Visiting my student's page on social networks, I saw shocking photos and statuses, which are not be proper to an eight-year-old girl... The environment becomes horrible. Unfortunately, the virtual world replaces the real world for children...".

Ruslana K.: "While in practice, I saw such a horrible case of child aggression: a 2 nd grade boy was so uncontrollable that I was shocked with his daily outburst of anger at his peers."

Ulyana B.: "Children are lonely both at home and at school, so they immerse themselves in their world, where there are interesting computer games; in cyberspace they have many friends. This is an important sociopedagogical problem, because students focus their potential not on learning, but on games... The desire to become independent, in my opinion, is actually a denial of the desire to be with people who love you... ".

After pedagogical practice in primary school, graduates of the Faculty of Education admitted that they were not disappointed with their occupational choice $(73.2 \%$ of respondents), partially disappointed $-23.7 \%$ of respondents. Obviously, the uncertainty in the ability to perform properly the functions of pedagogical activities in practice is determined by the lack of formation of those professionally significant qualities that are considered a priority. After all, they feel anxious about the idea of independent teaching (10.3\%), partially anxious $67 \%$ of the total number of respondents; mostly due to the typical difficulties they faced during the period of pedagogical practice in primary school. Namely: "difficult" students, prone to delinquency or excessively spoiled by parental attention (52.6\%), lack of practical skills of establishing pedagogical communication (39.2\%), inability to maintain discipline in the classroom (30.9\%), lack of theoretical knowledge in certain disciplines (15.5\%), difficulties in communicating with students' parents $(9.3 \%)$, authoritarian style of administration and teaching staff of the school (4.1\%).

In conditions of constant pedagogical interaction with students, their parents, teachers, school administration and other employees, future professionals have the opportunity to study, analyze and reflect on the experience of socio-pedagogical activities in primary school, understanding the need for professional self-improvement and development of own creative resources.

The results of students' individual projects based on pedagogical practice at school should be used to the maximum for a diploma (master's) study. At the same time, it is expedient to involve future teachers in a deep independent study of the best pedagogical experience tested in the conditions of this school, in order to transmit its substantiation from the practical to the methodological and psychological-pedagogical level. After all, a student's conscientious work on a diploma project is the basis for his/her future research work. 


\section{CONCLUSIONS}

The combination of theoretical and practical teacher training, the integration of teaching with research and experimental work will contribute to the practical orientation of the educational process at the university, the active search for and implementation of non-traditional forms and methods of teaching. Students' pedagogical practice is an integral part of a holistic process of professional training for socio-pedagogical activities, because of which they enrich their theoretical and methodological knowledge, master practical skills, skills of social and educational interaction in micro-society, develop personally, and professionally significant qualities, carry out pedagogical reflection in the aspect of selfknowledge and self-improvement. Teachers who are able to think critically, have a flexible mind and possess digital technology, are able to adapt to innovations and implement them in working with students, are doomed to success in the modern school.

During pedagogical practice in primary school future teachers should focus on the following tasks: the use of various forms and methods of socio-cultural education of students to prevent antisocial behavior, behavioral technologies of socio-pedagogical activities of primary school; monitoring the student's behavior and diagnosing to identify his/her talents; intensification of parents' efforts solving a child's social and educational problems; identification of pedagogical ethics working with different categories of students and their parents; creation of moral and psychological comfort in the social and educational environment of primary school; establishing cooperation with school colleagues to solve a child's specific problems; implementation of reflection of professional activity, etc.

The research was conducted within the framework of the fundamental scientific theme of the Center for Innovative Educational Technology "PNU-EcoSystem" Vasyl Stefanyk Precarpathian National University "Teacher training: socio-pedagogical context" (2017-2027) the state registration number is $0119 \mathrm{U} 101096$.

\section{REFERENCES}

[1] Budnyk O. Socio-pedagogical activity of a primary school teacher: teaching manual. PP Boichuk A. B., IvanoFrankivsk, 2012. (in Ukrainian)

[2] Budnyk O., Nikolaesku I., Atroshchenko T., Shevchenko A., Chinchoy A., Yatsyna S., Zobenko N. Professional training of teachers for social and pedagogical activity: progressive world practices. Revista Inclusiones, 8 (Especial / Enero - Marzo) (2021), 20-31.

[3] Budnyk O., Zozuliak-Sluchyk R., Nedilskyi S., Chervinska I., Malaniuk T., Prevysokova N., KetsykZinchenko U. Modern Digital Distance Learning Technologies: Challenges of Future Teacher Training. Revista Inclusiones, 8 (1) (2021), 41-53.

[4] Charalambous C.Y., Philippou S., Olympiou G. Reconsidering the use of video clubs for student teachers' learning during field placement: Lessons drawn from a longitudinal multiple case study. Teaching and Teacher Education, 74 (2018), 49-61. doi: 10.1016/j.tate.2018.04.002

[5] Higgs J. Practice-Based Education Pedagogy. In: Practice-Based Education: Perspectives and Strategies. Sense, Rotterdam, the Netherlands, 2012. doi: 10.1007/978-94-6209-128-3

[6] Kopanytsia K. Technological approach to modeling didactic situations. Bulletin of Lviv University, 25 (2) (2009), 170-177. (in Ukrainian)

[7] Law of Ukraine "On the involvement of employers in training and retraining, educational and scientific processes". Available at: https://job.tntu.edu.ua/zakon1/. (in Ukrainian)

[8] Palshkova I.O. Formation of professional and pedagogical culture of the future primary school teacher: practice-oriented approach, abstract of PhD in Pedagogics: 13.00.04. Odessa, 2009. (in Ukrainian)

[9] Sherin M.G., Han S.Y. Teacher learning in the context of a video club. Teaching and Teacher Education, 20 (2) (2004), 163-183. doi: 10.1016/j.tate.2003.08.001 
[10] Yevtukh M.B. Pedagogical practice. In: Kremen V.H. (Ed.) Encyclopedia of Education. Academy of Pedagogical Sciences of Ukraine. Yurinkom Inter, Kyiv, 2008. (in Ukrainian)

[11] Vasianovych H., Budnyk O. The Philosophical Foundations of the Researches of the Inclusive Education. Journal of Vasyl Stefanyk Precarpathian National University, 6 (1) (2019), 9-18. doi: 10.15330/jpnu.6.1.9-18

[12] Zaveryko N.V. Technology of social / socio-pedagogical work. In: Zvierieva I.D. (Ed.) Encyclopedia for social workers, 2nd edition. Universum, Kyiv - Simferopol, 2013. (in Ukrainian)

Address: Olena Budnyk, Vasyl Stefanyk Precarpathian National University, 57 Shevchenko St., Ivano-

Frankivsk 76018, Ukraine.

E-mail: olena.budnyk@pnu.edu.ua.

Received: 03.02.2021; revised: 19.03.2021.

Будник Олена. Практико-орієнтований підхід у системі професійної підготовки майбутніх учителів до соціально-педагогічної діяльності. Журнал Прикарпатського університету імені Василя Стефаника, 8 (1) (2021), 24-34.

У статті визначено теоретичні аспекти щодо соціально-педагогічного спрямування виробничої практики майбутніх учителів початкової школи. Окреслено завдання виробничої (педагогічної) практики як обов'язкової складової професійної підготовки майбутнього фахівця. Обгрунтовано необхідність залучення роботодавців до співпраці із закладами вищої освіти для забезпечення високого рівня безперервної практичної підготовки, створення умов ддя професійного розвитку й самореалізації майбутніх учителів. Наголошено на потребі творчого використання теоретичних знань і практичних умінь у роботі з учнями, сучасних технологій навчання, виховання й соціального розвитку школярів, а також систематичному професійному самовдосконаленні й саморозвитку. 3'ясовано, що у системі професійної підготовки вчителя виробнича практика виконуе низку важдивих функцій: навчальну, розвивальну, виховну, діагностично-корекційну, комунікативну, організаторську (управлінську), прогностичну, попереджувально-профілактичну та ін. Приведено орієнтовний зміст цієї практики студентів в умовах загальноосвітнього навчального закладу 3 урахуванням таких напрямів, як: робота 3 девіантними та обдарованими учнями, інкдюзивна освіта, соціокультурна анімація тощо. Представлено резудьтати емпіричного дослідження щодо готовності випускників педагогічних спеціальностей до практичного використання соціально-виховних технологій у школі. Виявлено труднощі, з якими найчастіше стикаються респонденти у роботі 3 учнями, серед яких: робота з різними категоріями батьків, індивідуальне консудьтування учнів, вирішення педагогічних конфдіктів, здійснення діагностичної діяльності та соціадьно-педагогічної комунікації тощо. Автором доведено, що поєднання теоретичної і практичної підготовки педагога, інтеграція навчання 3 науково-дослідною та експериментальною роботою сприятимуть практичній спрямованості освітнього процесу в університеті, активному пошуку та впровадженню нетрадиційних форм і методів навчання, зокрема у соціально-педагогічному аспекті.

У статті частково використано матеріади авторської дисертації “Теоретичні і методичні засади професійної підготовки майбутніх учителів початкових класів до соціально-педагогічної діяльності" (2015) на здобуття наукового ступеня доктора педагогічних наук.

Кдючові слова: професійна підготовка вчителя, початкова школа, виробнича практика в школі, практико-орієнтований підхід, педагогічний університет, соціально-педагогічна діяльність. 